\title{
Labeling Index and Cellular Density in Palatine Shelves of Cleft Palate Mice
}

William J. Mott

Loyola University Chicago

Follow this and additional works at: https://ecommons.luc.edu/luc_theses

Part of the Medicine and Health Sciences Commons

\section{Recommended Citation}

Mott, William J., "Labeling Index and Cellular Density in Palatine Shelves of Cleft Palate Mice" (1968). Master's Theses. 2246.

https://ecommons.luc.edu/luc_theses/2246

This Thesis is brought to you for free and open access by the Theses and Dissertations at Loyola eCommons. It has been accepted for inclusion in Master's Theses by an authorized administrator of Loyola eCommons. For more information, please contact ecommons@luc.edu. (c) $($ ) $\Theta \Theta$

This work is licensed under a Creative Commons Attribution-Noncommercial-No Derivative Works 3.0 License. Copyright @ 1968 William J. Mott 


\section{IABELING INDEX AND CELIULAR DENSITY \\ IN PALATINE SHELVES OF \\ CLEFT PALATE MICE}

BY

WILIIAM J. MOTT

A Thesis Submitted to the Faculty of the Graduate School of Loyola University in Partial Fulfillment of the Requirements for the Degree of

Master of Science

MORARY

LOYOLA UNI WHSTY MEDICA OENTE

JUNE

1968 


\section{AUTOBIOGRAPHY}

william J. Mott was born in Chicago, Illinois on October 5,1937 .

In September, 1956 he entered the University of California at Los Angeles. He received the degree of Bachelor of Arts in zoology in June, 1960.

He entered Loyola University School of Dentistry, Chicago, Illinois in September, 1962. In June, 1966, he received the degree of Doctor of Dental Surgery.

In June, 1966, he began graduate studies in the Department of Oral Blology at Loyola University, Chicago, Illinols. 


\section{ACKNOWLEDGEMENTS}

I wish to express my sincere appreciation to all those who have alded in making this investigation possible, particularly to the following:

To Joseph R. Jarabak, D.D.S., Ph.D., my appreciation to his devotion to the orthodontic profession and for giving me the opportunity to study orthodontics.

To Patrick D. Toto, D.D.S., M.S., Professor of Oral

Pathology, my thesis director, for his advice, guidance and support in preparing this thesis.

To my wife, Iinda, for her never ending encouragement and understanding throughout my professional education. 


\section{TABLE OF CONTENTS}

CHAPTER

PAGE

I. INTRODUCTION AND STATEMENT OF PROBLEM 1

II. REVIEW OF THE LITERATURE 3

1. Normal Palatal Development

2. Cortisone Induced Cleft Palate

3. Cortisone Action

4. Autoradiography

5. Acid Mucopolysaccharides

III. MATERIALS AND METHODS 23

IV. FINDINGS 29

V. DISCUSSION 39

VI. SUMMARY AND CONCLUSIONS 44

VII. BIBLIOGRAPHY 46

VIII. APPENDIX 52 


\section{CHAPTER I}

\section{INTRODUCTION AND STATEMENT OF PROBLEM}

cleft palate is a congenital anomaly occuring once every 700-800 births. Despite this frequency, literature describing research on the embryology of cleft palate as well as normal palate development has been inadequately documented. Furthermore, the majority of this literature has been written within the last fifteen yeara.

As a result of this renewed interest, it is no longer sufficient to pass off the cause of cleft palate merely as a lack of growth of the palatine processes, or as a mechanical obstruction resulting from a fallure of the tongue to arop at the proper time. Recent investigations have serlously questioned these theories, and now the role of acld mucopolysaccharides in the connective tissue of the palatine shelves is of primary interest.

Thru histochemical and autoradiographic studies, various authors suggest a decrease in the acid mucopolysaccharides of a cleft palate mouse compared to a mouse w1th normal palatal development. Although some evidence has been advanced supporting this theory, the evidence is "semin-quantitative and has 
been based on subjective interpretation of the various Investigators.

It is commonly accepted that the cells produce the acid mucopolysaccharides. The purpose of this investigation is therefore two-fold: to determine if there is either a significant aifference in the mitotic activity labeling index in the palatine shelves of the control and the treated mice; or if there is a corresponding Increase in cellular density relating to the decrease of the acid mucopolysaccharides in the intercellular material. 


\section{CHAPTER II}

REVIEW OF THE IITERATURE

I. Normal Ralatal Development

PolzI (1904) postulated that the palatine processes undergo horizontalization by regression of their ventral extremitles and concomitant new shelf growth from their modial surfaces at approximately the level of the tongue. PonsTortella in 1937 substantiated this theory of palatal closure.

Peter (1924) proposed the concept that the lateral palatine processes assumed horizontal position from a ventrally directed position by undergoing a medial rotation. Lazarro (1940) reaffirmed this theory and postulated the following ldeas to explain the mechanism of palatal shelf movement: 1. external pressure such as muscular pressure from the tongue; 2. growth changes involving regression of the ventral portion and an outgrowth in the horizontal plane, 3. rapid rotation of the shelves due to some intringle forces.

Lazarro favored the idea of rapid movement, and his studies indicated that rotation resulted from an increase of intarcellular substance within the lateral palatine processes. Thus the increased intercellular material (swelling of the 
shelves) caused the lateral palatine processes to rise once the obstruction of the tongue was renoved. Lazarro thought that the release of the tongue had to take place before anything else, even if the mechanlsm of release was "slightly obscure". He suggested the following mechanisms for the release of the tongue:

1. lowering of the mandible and tonque

2. forward displacement of the tongue

3. lifting of the roof of the oral cavity

4. changes in form of the tongue due to muscular development

5. muscular movements of the tongue

According to Reed (1933), the vertical palatine processes are rotated into a horizontal plane efther by unequal qrowth or by muscular contraction and growth in the horizontal plane continues until the palatal plates come in contact and fuse. Walker (1954) stated that the literature on the ambryonic development of the secondary mammalian palate appears reliable except for the stage of closure from the vertical to the horizontal position.

Walker described seven (7) stages of palatal closure. Stage 1: The primary palate and alveolus have already 
been formed. The medial portion of each palatine shelf lies in a vertical plane while laterally the shelf lles in a horizontal plane. At first, the tongue lies completely between the shelves, but later as the tongue increases in widh it spreads out across the shelves. From a ventral position, the posterior ends of the shelves cannot be seen.

The tongue, therefore, is ventral to the shelves poster1orly and medial to the shelves anteriorly. At the point where the tongue goes from ventral to medial, it makes a grooved impression on the sides of the shelves.

Posterior to the groove, the shelves slope at an obtuse angle away from the roof of the nasal cavity so that the medial surfaces are visible when viewed from the ventral. Anterior to the groove the shelves slope at an acute angle and thus tend to cup the tongue between them, and when the tongue is removed, the medial sides of the shelves are not visible from the ventral. Stage II: The groove has moved to a polnt mldway along the shelves.

stage III shelf activity is not necessarily synchronized bllaterally and at times a condition is seen where one shelf is completely dorsal to the tongue (horizontal) and the other is not. 
Stage IV: Both shelves have now assumed a dorsal position to the tongue. The shelves are at firct separated by a small space which is bridged by a further flattening of the shelves. Stage V: Fusion of the shelf epithelium begins. Stages VI and VII: Epithelial fusion spreads anteriox and posterior until the shelves are fused throughout thelr length. Thus Walker says that at the point of transition, where the tongue goes from a medial to a ventral position relative to the shelves, the shelves curve around the tongue in a twisting fachion. This twisting of the shelves over the tongue proceeds In a wave-like manner anteriorly until the whole shelf lies dorsal to the tongue. Walker further states that this hor 1zontaldxation of the shelves occurs without any active participation of the tongue. This is mphasized in histologic sections In which one shelf is horizontal while the other shelf is vertical. He says there is no sign of the tongue having dropped to allow the shelves to become horlsontal as suggested by Petar (1924) and Lazarro (1940).

Walker also says that the ldea of rotation of the shelves (Peter, 1924, Reed, 1933, Lazarro, 1940) 1s unsatisfactory because the relationohip of the tongue to the shelves does not suggest such a movenent since an intermediate shelf condition 
not involving rotation has been shown (bulging of the shelves along their dorso-medial surface, and a regression of the ventral protrusion).

Walker Indicated that the time required for shelf novement (stages 2,3 , and 4) is 3 hours and the time required for fusion (stages 5 and 6) is 6 houra. By experimentally inducing shelf movement, walker showed that the shelves can change position within ainute when the tongue 1 s manually displaced, Resistance of the tongue accounts for the lengthy pertod required for shelf movement. This discounts the proponents of a growth mechanism (Reed, 1933 and Pons-Tortella, 1937) although they were close to being correct in their theory of how the shelves by-passed the tongue (xesorption of the vertically allgned ventral portion and an outward "growth" of the medial wall). Walker and Fraser (1956) stated that the metachromasia and affinity for aldehyde-fuchsin of the shelf connective tissue suggests two posalble mechantsms for ghelf mobility:

1. Lazarro' theory of tissue turgor could implicate hyaluronic acld as ater barrier and the acid could account for the metachromasia, (Walker ruled this out however because the dehydrating effect of 70 aloohol on ghelf movement was Ineffective,) 2. Also, he suggested that shelf movenent is 
due to the tensions of a developing network of elastic fibers. (They thought that the metachromasia was consistent with an interpretation of elastic fibers.)

By 1960, Walker had discarded his "elastic flber" theory of ohelf movement and suggested the force for palatine shelf movement is contained in the sulfated acid mucopolysaccharides of the mesenchymatous ground substance. By using autoradiographa derived from embryos recelving $\mathrm{s}^{35}$, Walker (1961) whowed a greater Intensity of palatine tisaue radoactivity in embryos recelving $8^{35}$ from day $14 / 8$ to $14 / 18$ than from embryos recelving $\mathrm{s}^{35}$ from day $12 / 10$ to $14 / 8$. Thls can be constdered as evidence indloating a sulfated acid mucopolysaccharlde synthesis causing a bulld up of palatine whelf force since palatal closure is known to take place from day $14 / 8$ to $14 / 20$. It should also be noted that sulfation Increases the viscosity and gelation of actd mucopolyacchartdes (Toto).

In 1961, Larseon proposed the theory that 1) the elasticity of the ground substance permitis a change in the fibroblast zones, and that it can be presuned that, 2) changes in the polymerization and/or aggregation of the high molecular weight mucopolysaccharides, and/or binding of water to them gives rise to tensions or changes in pressure in the tissue 
resulting in development of a force which causes changes in shape. Iarsson therefore considers the presence of chondroitin sulfuric acld, a sulfated acid mucopolysaccharide with powerful synthesis in the ground substance of the flbroblast zones, as responsible for the internal force.

Larsson also agrees with Walker's theory of palatal closure and says the internal force is sufficiently strong to cause the palatine shelves to bulge over the tongue.

Asling et al (1960) said that the lateral processes of normal rat fetuses rotated from a ventromedial to a horizontal plane in the rostral region of developing palate, however palatal closure caudal to the choanae was not described. They thought that the elevated position of the tongue in the floor of the mouth in letuses with cleft palate acted as a barrier to the palatal processes.

As late as 1965, Coleman sald that the rostral segment of rat palate closes in accordance with the rotational theory of Peter (1924) and Lazarro (1940) and the caudal segment in accordance with the mechanim of transformation described by Polz1 (1904) and Pons-Tortella (1937).

Cortisone Induced cleft Palate

In 1950, Baxter and Fraser discovered that cortisone 
could induce cleft palate in developing mice. Two strains of mice were used in their investigation, and in neither strain was cleft palate found to occur spontaneously, except in conjunction with cleft 11p. The alveolar ridge was not disturbed in the cortisone induced cleft palate.

By giving varying doses of cortisone for varying lengths of time to pregnant female mice, Fraser and Fainstat (1951) showed that the A/Jax strain was the most susceptible to cleft palate formation. Cortisone injectlons started on the loth or 11th day showed the highest incldence of cleft palate in the offspring. Fraser at al (1954) and IsaccBon (1962) showed a 1008 incidence of cleft palate in $\mathrm{A} / \mathrm{Jax}$ mice treated with $2.5 \mathrm{mg}$. cortisone for four days beginning on the loth or 11th day. The incldence of cleft palate declines markedly when treatment is started after 11 days (1.e. 298 on the 12 th and 13 th days) Fraser and Falnstat (1951).

Ingalls and Curley (1957) reported that 5 and $10 \mathrm{mg}$. doses of hydrocortisone injected at $11 \frac{1}{2}$ days of gestation produced 478 and 100 cleft palates respectively in albino mice. However, there were more fetal resorptions when $10 \mathrm{mg}$. was injected in a elngle dose.

Fraser et al (1954) suggested that congenital palatine 
clefts may be caused by two different mechanisms: one acting before the palate closed, causing delay in rotation of the palatine shelves, and one causing a regressive change in the palate after it closed.

Walker (1954) stated that when $\mathrm{A} / J a x$ mice recelved a particular schedule of cortisone infections, there was a delay In the average time and rate at which palate shelf movement occurred. He considars this without doubt, the primary cause of eleft palate in newborn mice from a cortioone treated mother. He sald that stage three (3) of palatal closure (one shelf vertical, one horizontal), which is normally infrequent, is found repeatedly throughout a wlde range of morphological and chronological ages in treated embryos.

The measurements of the palatal region did not show any sign of growth retardation at time of palatal closure due to cortisone treatment (Walker 1954). He also sald cleft palate develop in treated embryos with retarded shelf movement because fusion of the shelves is apparently necessary to stimulate shelf growth beyond the size seen during normal palate closure. The degree of delay of horizontalization of the shelves is varlable and the shelves that changed shape late in development (day 15/8) were only as wide as normal shelves starting to fuse. Head 
growth is not noticeably affected by cortisone during this perlod, so that the late moving shelves are drawn apart by increasing head width and when the shelves finally become horizontal, they are too far apart to touch and fuse.

walkex (1954) suggested that if cortisone treatment were affecting the shelves directly, there would be an inhibition in the build up or the release of the force causing shelf movement. Walker thought that cortisone was inhibiting the growth of fibers, or the plasticity (acid mucopolysaccharides) of the tissue, or even the spatial relation (pattern) of fibers and tissue masses that lead to a change in the type of configuration, giving maximum stability.

Larsson (1961-62) shows that cortisone administration lowers the sulfate incorporation into the sulfated acid mucopolysaccharldes of mouse embryos. He agreed with Walker and Fraser (1956), that the shelves are retarded in horisontalization and that cortisone in the palatine shelves can interfere with substances presumed to be responsible for the internal force (acid mucopolysaccharldes). He also presumes there are changes in polymerization and/or aggregation of the high molecular weight mucopolysaccharides and that there is a change in pressure in the tissues. In 1961, Walker also attributed 
the decrease in acid mucopolysaccharides as the cause for retardation of the build up of the shelf force.

Ralter (1957) stated the elements so far discovered that interact to determine a particular frequency of oortisone induced cleft palate are: dose of homone, gestation time, mouse strain, maternal genotype, fetal genotype, maternal weight and fetal welght. He showed that the frequency for control litters to be completely resorbed was 2.78 compared to 28.68 in treated litters. Cortisone decreased litter size by approximately 30\%, and the cleft palate newborn welghed less than the1r normal litter mates. The heavier the mother or the more advanced the par1ty, the lower the eleft palate frequency.

Leovy (1962) Injected $1.25 \mathrm{mg}$. cortlsone daily from the 11th to the 14 th day and achleved 100 s cleft palate formation wth low fetal resoxption. She sald it is unlikely that the tongue plays an active role in the process of cleft palate formation and unilkely that horizontalization is a significant factor, and furthermore stated that it was unlikely that connective tisgue plays an Important role in the development of the cleft. She says that if there was an inhibition of connective tissue growth at the moment when the palatine shelves were in close proximfty, the delay could be fatel to normal 
development because further development of the head would preclude a later fusion of the shelves. She states she has observed a breakdown in basement membrane in early stages of fuston, while in later stages the basement membrane has become reorganized. In two (2) of the experimental animals, an Intact basement membrane was seen at 15 and 16 days, when shelves were contiguous. Ioevy says these shelves would not have fused and that they would have pulled apart. This theory is not well documented however.

\section{Cortisone Action}

The exact mechanism of cortisone action on the palatine shelves is at present unexplained. It is not known whether cortisone acts directly on the shelves or whether there is an intermediate step before the action is manifest. For the above reasons, a review of the effects of cortisone on connective tissue is indicated.

Layton (1951) sald that high doses of cortisone appeared to Inhibit the synthesis of chondroitin sulfate from the tissues. He sald this effect may be secondary to the alteration in protein metabollsm indicated by a large negative aulfur balance. A fallure to form hexosamines could be partly 
responsible for the alsappearance of chondroitin sulfate from the tiasue; a simultaneous decrease in all mucopolysacoharldes would then be expected.

Bullough (1932) auggested that cortisone had a general antinitotic action. Bullough did state, however, that the disturbance in carbohydrate metabolian may bo factor in depressing cell division. In another Investigation it was found that the effect of cortisone on mitosis varies from one type t18sue to anothar and that it does not seem likely that one of the fundamental, universal actions of cortisone is to Inhibit mitosis. Roberts at al (1952).

Cavallero and Braccint (1951) found that metachromatically stainable material had practically disappearad from the connective interftbriliar tissue. Paff and stewart (1953) found that the mast cells were reduced in number. It is known that cortisone inhibits new formation of connectlve tissue. Asboe Hansen (1952) found flbroblasts in healing wounds of treated (cortisone) Individuals are smaller and more pynknotic than in wounds of untreated individuals. He also found a decrease in the number of mast cells.

Prolonged treatment wth cortisone inhibits both hyaluronidase and streptococol. B1rke (1953). 
Lattes et al (1953), found that in injared mesenchymal tissues treated with cortisone, the metachromasla of the ground substance is reduced, suggesting that the mucopolysaccharides of the connective tissue do not undergo the same chemical changes as in untreated urinjured animals. Ashton and cook (1952) found generalized vascular constriction and depression of capillary pemeability in rabbit ear chamberg after cortisone administration.

In skin wounds, development of granulation tissue was markedly delayed in all cases where cortisone was administered. Ragan et al (1949). There was no signiflcant influence on the composition of the existing granulation tissue, or evidence of Iysis of the granulation tisgue. Spain et al (1950).

\section{Autoradlography:}

With the use of autoradlography, radioisotopes may be localized to an organiem, an organ, an area in a histologio section, or even to individual cells. The object (tissue) to be studied is placed against photographic emulsion allowing sufflelent time for exposure and then developed as in ordinary photography. The processed photographic emulsion 18 called an autoradiogram and consists of accumulations of black granules 
overlyling those areas in the tiseve section which contaln the radiouctive material. The photographio aulsion recorda in 1ts cryatale of silver bromide the loniaation produced in the emulston by rapidly moving charged particles or radiation. (Fitagerald, 1953, Bohoenhelder, 1960).

"The chemlcal bohavior of a labeled eubstance is identical with that of 1te stable counterpart. This is also true of its blological behavior provided (1) the amount of radioactivity adninistered is mall enough not to have a significant radiochemioal effect, and (2) the amount or welght of material Injeoted be suffictently amall not to produce a significant Inerease in the amount of the substance in the circulation. The Iabeled subetance will then truly act as a "tracer" of normal metabolim." schoonheldex (1960).

In 1959, Leblond, et al investigated the possibility of using tritlated thymaline for tudying renewal of cell populatione utilising the mouee tongue. Also in 1959, Cronkite, et al ut1lized autoradograme in the etudy of DNA synthesis, and cell turnover in hemopoietio tisgues. Fhay stated that "although thymidine is appaxently not a normal precurgor of DAA, it can enter the eynthetic chain and label DNA at the time of DaA doubling prior to mitosia. Thus if the label is 
sufficlently Intense and permanent, one can, by autoradiography, follow cells from the time of DNA oynthesis to ultimate death." Hughes et al (1958) stated that: "In oxder to distingulah eell renewal from the renewal of cellular constituents, the Iabel muet be Incorporated into a fixed component of the cell which is not lost during the cells life time; and present knowledge auggents that a label incorporated into DNA should be most useful for this purpose. The specific advantage of labeled tritium lles in very high rasolution which can be obtalned because of the very weak energy and consequently short range of its beta radiation. The maximum range in tissue of a beta ray from txitium is only six microns and half of the betas will travel less than one micron. Consequently, the activated silver grains to an autoxadiogran shoule largely ile within one mioron of their source. Iritiated thymidine is apparently rapialy aborbed by all cells when injected into nice. The concentration of tritiun hydroxice raachos a maximum within one hour following intraperitonoal injection. wherefore, tie precursor pool of DNA oynthesis must simultaneousiy becone exhausted suggenting that all labeling of nuclei oocurs auring the let houx after lnjection. This aloo moans a similar rafe of exhaustion of thymidine from DNA synthesizing cells as from 
tissue as a whole."

Lajtha et al (1959) also showed thymidine was a specific component of DNA and that it labels only DNA. They noted an eight micron maximum and an average of 1.5 microns. Tritium has a half life of 12.26 years and a disintegration rate of 0.0168 ay.

Leblond et al (1959) stated that it is known that mitosis is preceded by a synthesis of DNA. If a radioactive DNA precursor is administered at the time of DNA synthesis, the nucleus becomes radioactive and may be recognized by autoradiography prior to mitosis. The labeled nuclei pass the label on to the daughter cells. The danger of radiation damage seems to be reduced with tritium, and it is possible to use doses which allow cells to be tracea over periods of months in the body without apparent signs of damage to these or other cells. Furthermore, the sections need not be subjected to chemical extractions since DNA is the only labeled substance present in significant amounts in the sections following $\mathrm{H}^{3}$ aoministration. DNAase treatment eliminates all autoradiographic reactions.

The photographic grains produced by tritium containing structures are found within two or three microns, due to the Low beta-ray energy of tritium, and most of them within one 
micron from the source as measured within NTB-3 emulsion. "It may be concluded that thymidine $\mathrm{H}^{3}$ is an adequate tool for the autoradiographic direction of newly formed DNA and therefore, may be used to locate the sites of cell formation." Schoenheider (1960).

\section{Acid Mucopolysaccharides}

The term polysaccharide is generally limited to those polymers which contain ten or more monosaccharide units. The size of polysaccharides is variable, but most natural polysaccharides are high molecular weight, containing some 100 to 1000 monosaccharide units. Mucopolysaccharides are most often defined as compounds having a low, but significant protein content but whose reactions are predominently polysaccharide. The ground substance of connective tissue contains a large amount of mucopolysaccharldes and mucoproteins. The acid mucopolysaccharides present in the connective tissue are: hyaluronic acid, chondroitin sulfate $A, B$ and $C$, heparin and keratosulfate. All of these are sulfated with the exception of hyaluronic acid. Most mucopolysaccharides do not exist as free compounds, but are linked to protein. Dorfman (1961).

There are two theories regarding the source of the mucopolysaccharides of the ground substance. Most investigators 
consider the oxigin to be from the fibroblasts. The presence In flbroblasts of granules and vacuoles having the histochemical reactions of mucopolysaccharides and the occurence of large amounts of mucopolysaccharides in certain types of fibrosarcoma Favors the 1bbroblast. (Gersh and Catchpole, 1949). In scorbutus, where the flbroblasts remaln immature and the formation of collagen from reticulum is interfered with, the metachromatlc substance persists long after 1ts almost complete d1sappearance from the completely healed wounds in the normal animals. (Bunting, 1949). The other theory 1s that the mast cell is the source of mucopolysaccharldes. (Asboe-Hansen, 1951). The mast cell is known to store, if not synthesize, heparin.

Chondroltin sulfate $A$ is of primary interest since it ia the main mucopolysaccharlde of cart1lage. These and other sulfated mucopolysaccharldes occur in tissues whioh are normally in a state of dehydration. They have been connected with fibrogenesis and with the binding of cations. Karl Mayer (1954).

Dorfman (1954), atates that the acid mucopolysaccharldes are flexible chain polymers of high negative charge with a high affinity for cations and water molecules and suggests they may play critical role in regulating the metaboliam of inorganic Lons and water. A change in concentration or molecular size of 
such a substance would then be of great importance in modifying the capacity of connective tissue to bind water and salts. 


\section{CHAPTER III}

\section{MATERIALS AND METHODS}

I. Animals

\section{Mice:}

Thirty A/Jax atrain mice (20 female, 10 male) were

obtained from the Jackson Laboratory when they were 41 days old. These mice have been inbred for over 114 generations and were chosen because of their susceptibility to cortisone induced cleft palate. Fraser and Fainstat (1951).

\section{Mating:}

During the period that the mice were being mated, males and females were grouped in cages on Monday evenings, and were removed on Friday mornings. The females were examined for vaginal plugs each morning between $0: 00$ and 11:00 A.M. If for some reason the females could not be checked on a given day, the males were removed from the cages the day before. Due to a limited amount of room, apecified method of mating was not used. In the beginning, 2 males were placed in cages with 4 females. Later, as the number of virgin females was reduced, the ratio of male to female varled from $2: 3,2: 2,2: 1$, and $1: 1$. When a vaginal plug was identified or suspected, the 
female was isolated. The date the plug was found was written on the isolation cage and identified as day zero of pregnancy.

2:00 A.M. was selected as zero hour in assigning ages to mbryos. snell et al (1940). In order to insure proper tining of the embryos, the morphological criteria of Gruenberg (1943) were used to grade the embryos.

Cortisone Injections:

$2.5 \mathrm{mg} .(.1 \mathrm{co}$.$) of cortisone was injected into the flank$ of the pregnant females at 12:00 P.M. on the 11th, 12th, 13th and 14 th days of gestation as estimated by the vaginal plug. The cortisone used was the Merck Cortone (R) preparation, a saline suspension which contains cortisone acetate ( $25 \mathrm{mg} / \mathrm{cc}$.) with added suspending agents and 1.58 benzyl alcohol. The control females were infectea with . I cc. of sterile isotonic saline solution at the same time as the cortisone treated females.

\section{Gross Anatomy:}

All pregnant females were injected with $.5 \mathrm{cc}$. labeled thymidine (sp ac. $1.9 \mathrm{c} /$ mole) peritoneally 1 hour prior to sacriflce. The mice were sacriflced by ether overdose at 15b and $16 \frac{1}{2}$ days in utero. The uterus was removed and placed in Bouln's fixative from 2 to 4 days. The embryos were then 
dissected out under a binocular dissecting microscope and the heads were detached from their bodies. The heads were then stored in $75 \%$ alcohol. The lower jow and tongue were removed from several of the embryos in order to examine the palate under the dissecting microscope.

\section{Microscopic Anatomy:}

Embryo heads with and without the lower jaw and tongue were used for histologic study. The embryo heads were embedded in parafin and sectioned at 5 microns. Each loth slide was stained with hematoxylin and eosin for cellular and area identiflcation. The staining procedures are those described in MoManus .

Staining materials used:

1. Hematoxylin and eosin

2. PAS (Periodic Acid Schiff)

3. Alcian Blue-Aldeinyde fuchsin

4. Alcian Blue-PAS

5. Azure A extinction pH $0.5,1.0,1.5,2.0,2.5$, $3.0,3.5,4.0,4.5,5.0,5.5,6.0$.

The above histochemistry procedures were used to compare differences in staining capacities during varlous stages of palatal development. Larsson (1961) and Loevy (1962) could not 
show any differences in staining intensities between cortisone induced cleft palate mice and normal mice. Jacobs (1964) showed striking differences in staining reactions in both experimental groups during the perlod of palatal closure. Autoradiographie rechnlgue:

The technique used for autoradlography was modifled from that described by Fitsgerald. (1951)

1. Bnder dark room cond1tions, A Wratton 11 , Red gafel1te 10 watt bulb is used, $A$ humidity of 708 and below is recommended.

2. The slide is alpped in MTB 3 Lquid enulaton (Kodak). 3. The alide is air dried for 10 minutes.

4. Ten elldes are placed in a blaek, light proof exposure box, seotionssides up. Itthium ohloriae is placed in the box for maintaining a low humidity and blaok masking tape Is used to seal the box.

5. The box was exposed for 30 daya at low hunldity and temerature. During the exposure time the bax must be malntained in a position whlch keepa the sections upright. Dereloping:

1. The slides are placed in staining raak and Ceveloped for 5 minutas at $60^{\circ} \mathrm{F}$. (18\% $\mathrm{C}$. In Kodak D196 developer) 
2. The slide is rinsed in distllled water for 30 seconds.

3. The slide is then placed in acla fixer for 10 minutes.

4. The slide is rinsed in running tap water for 30 minutes.

5. The slides and staining dish are covered with kleenex (to prevent dust from settling on the slides) and allowed to dry in a stream of air.

\section{Cell Counts:}

In order to be consistent in the selection of sections through the palate, only sections which included the nasal septum were utilized for cell counts. The base of the palatine shelf was the region used for recording cell counts.

1. Mitotic Labeling Index: Under high dry magnification the number of labeled connective tissue cells per 1000 cells at the base of the palatine shelf were counted. Three or four black grains over a cell was the criteria for a labeled cel1. Four fetuses from each age group were utilized in the counting. The number of labeled cells/1000 cells were counted for aach fetus.

2. Cellular density: The number of connective tissue 
cells per $.25 \mathrm{~mm}^{2}$ were counted for each fetus. A micrometer was placed over the connective tisgue at the base of the palatine shelf and an average was obtained for each fetus. 
CHAPTER IV

FINDINGS

Figure IA demonstrates an H\&E section of a $15 \frac{1}{2}$ day normal mouse palate. All sections used in counting included the nasal septum for area identification. The palatine shelves have undergone horizontalization and have fused at this stage of development.

Figure IB demonstrates an autoradiograph at the base of the palate of a $15 \frac{1}{2}$ day normal mouse palate.

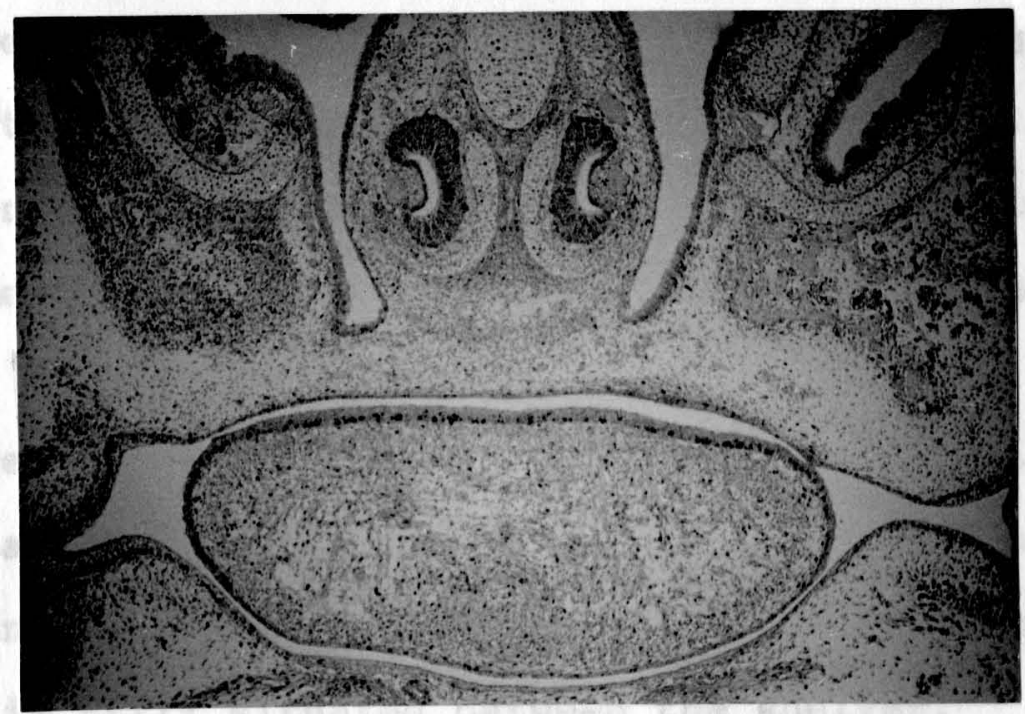

Fig. 1A (40X) 


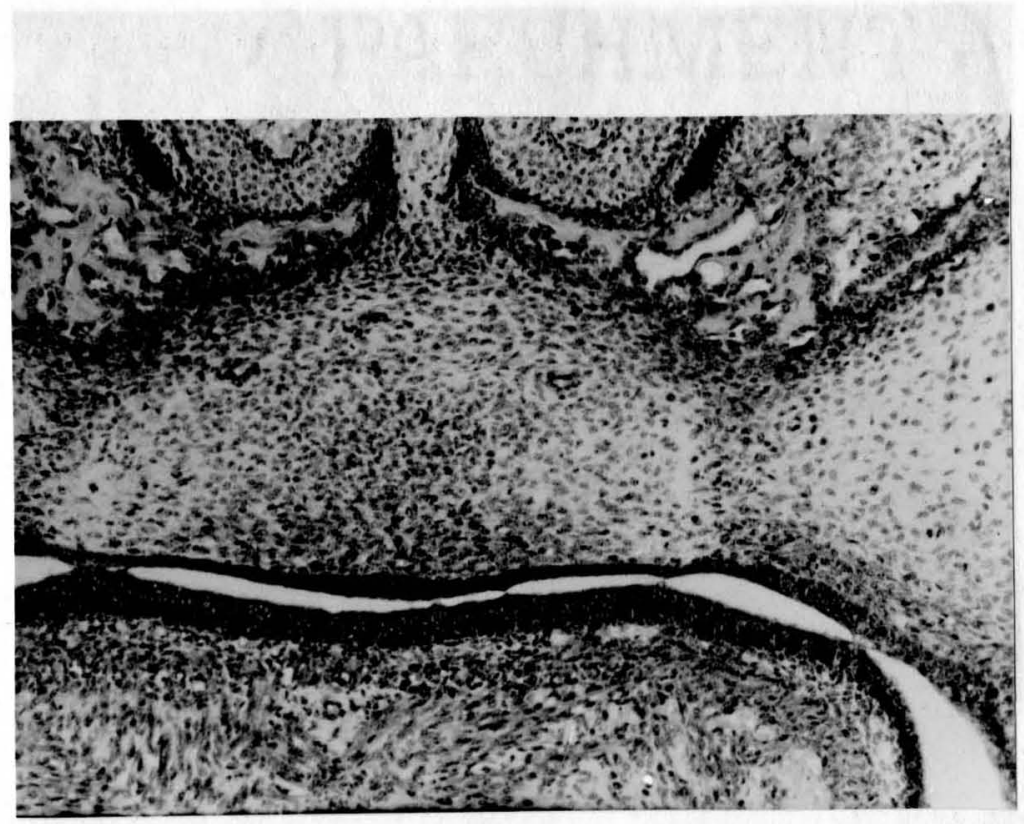

Fig. $1 B$ (1200X)

Figure 2A demonstrates an $\mathrm{H} \& \mathrm{E}$ section of a $15 \frac{1}{2}$ day mouse with a cleft palate. The palatine shelves are still in a vertical position and the tongue is interposed between the palatine shelves. The tongue appears compressed due to the pressure of the palatine shelves.

Figure 23 demonstrates an autoradiogram of a $15 \frac{1}{2}$ day mouse with a cleft palate. The palatine shelf has not undergone horizontalization, but appears at a more oblique angle. The tongue is still situated between the shelves. 


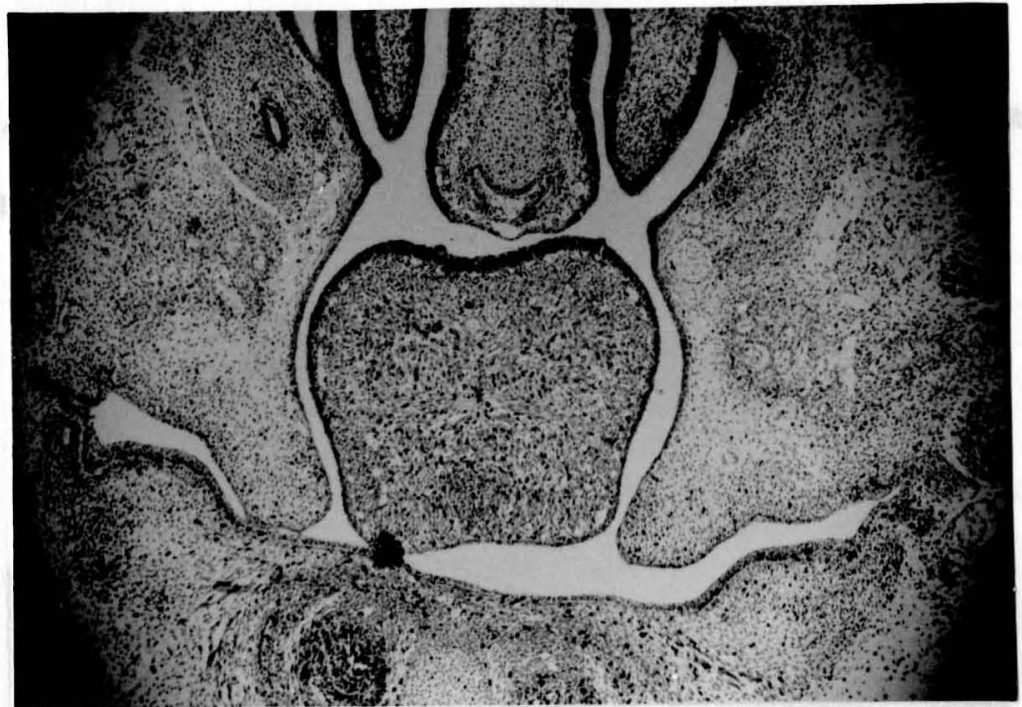

Fig. $2 A(40 \mathrm{X})$

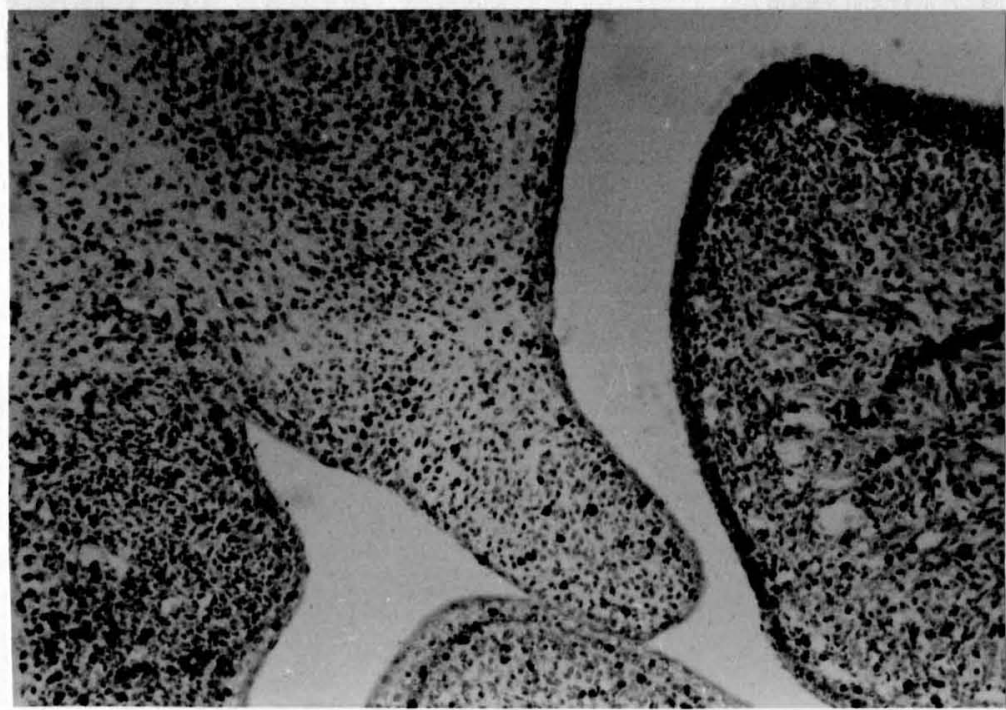

Fig. 2B (100X) 
Figure $3 \mathrm{~A}$ demonstrates an $\mathrm{H} \& \mathrm{E}$ section of a $16 \frac{1}{2}$ day normal mouse palate. Figure 3B demonstrates an autoradiograph of a

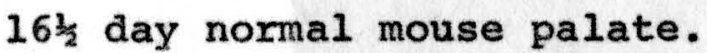

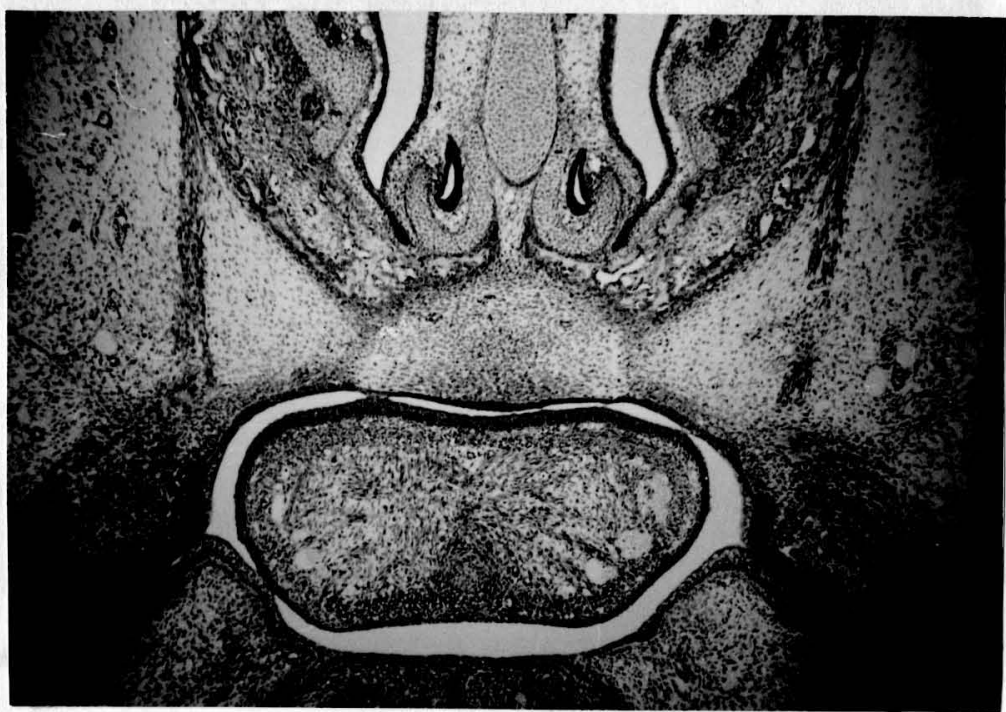

Fig. 3A (40X) 


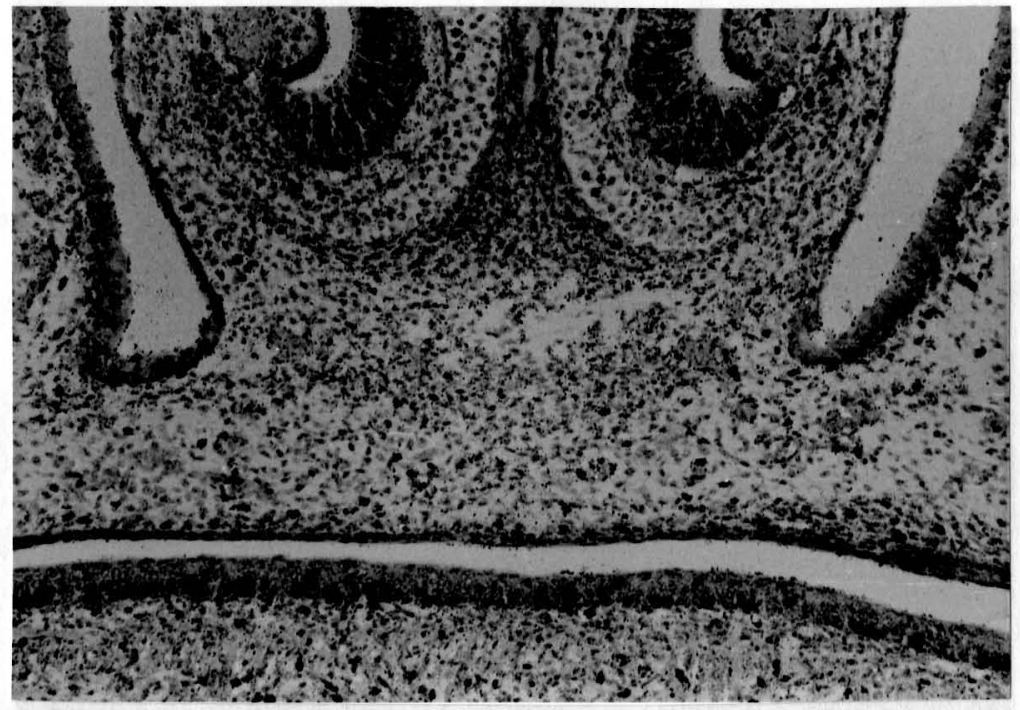

Fig. $38(100 x)$

Figure $4 \mathrm{~A}$ demonstrates an H\&E section of a $16 \frac{2}{2}$ day mouse cleft palate. The shelves have not yet undergone horizontalization. The tongue is still interposed between the shelves, but is lower and less compressed than in the $15 \frac{1}{2}$ day mouse.

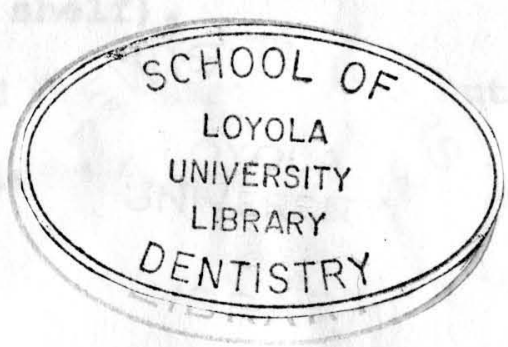




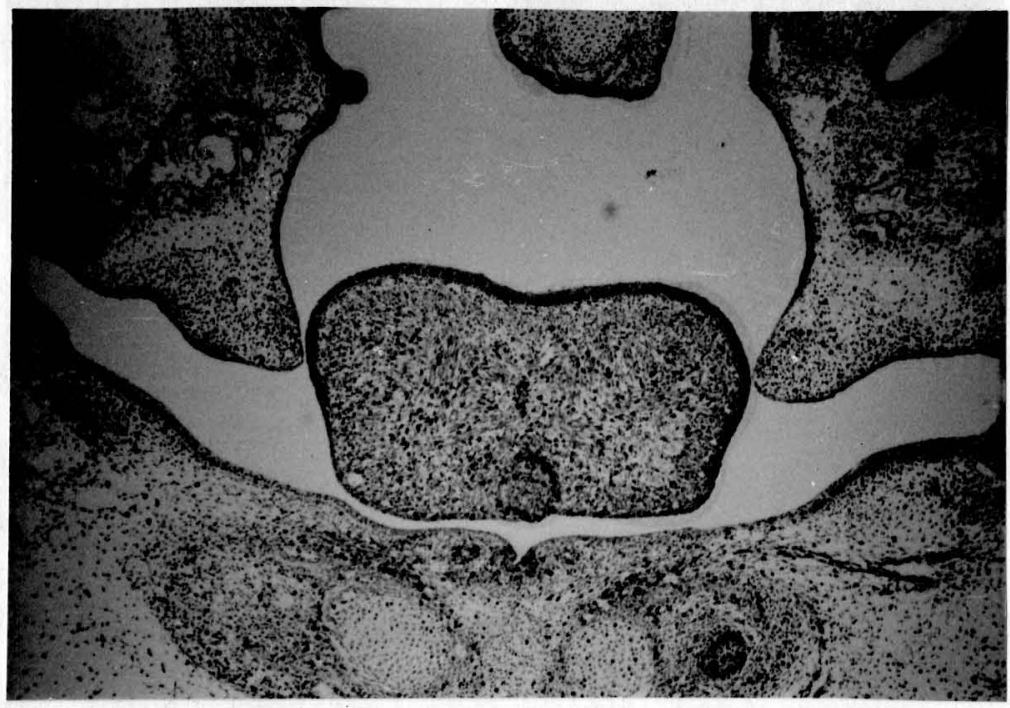

Fig. 4A (40X)

Figure $4 \mathrm{~B}$ also demonstrates an $\mathrm{H} \& \mathrm{E}$ section of a $16 \frac{1}{2}$ day mouse cleft palate in which one shelf is in a horizontal position and the other shelf is still in a vertical position. The tongue has not dxopped at this point. The shelves appear to be exerting pressure against the tongue as seen by its shape (i.e. pressed laterally by the vertical shelf and inferiorly by the horizontal shelf).

Figure $4 \mathrm{C}$ demonstrates an autoradiogram of a $16 \frac{1}{5}$ day mouse with a cleft palate. 


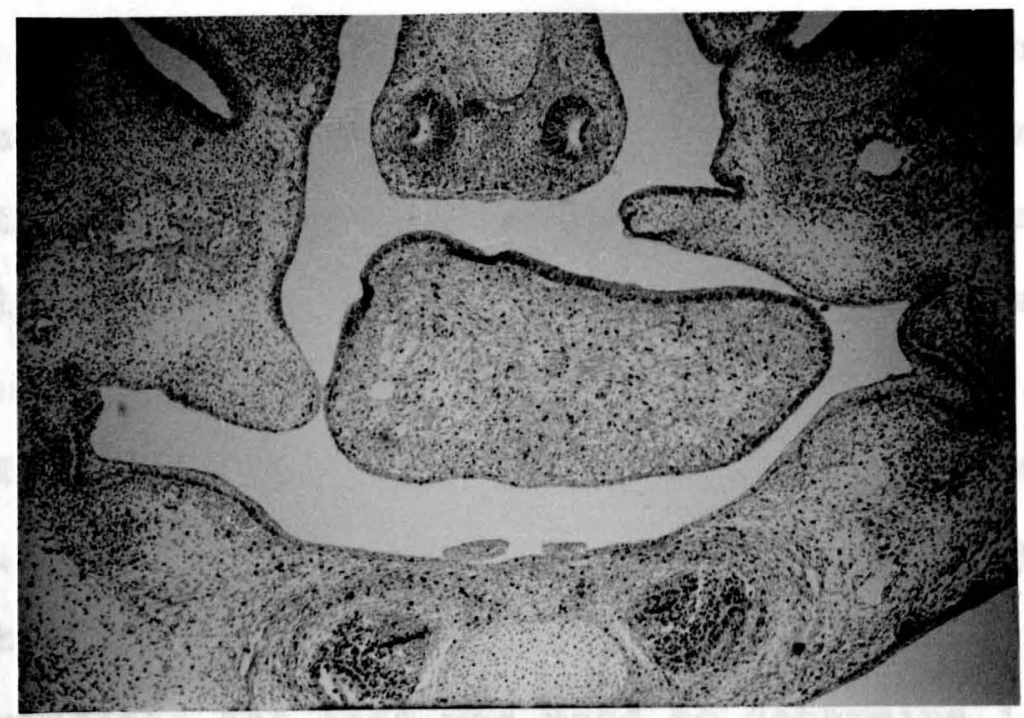

Fig. $4 B(40 X)$

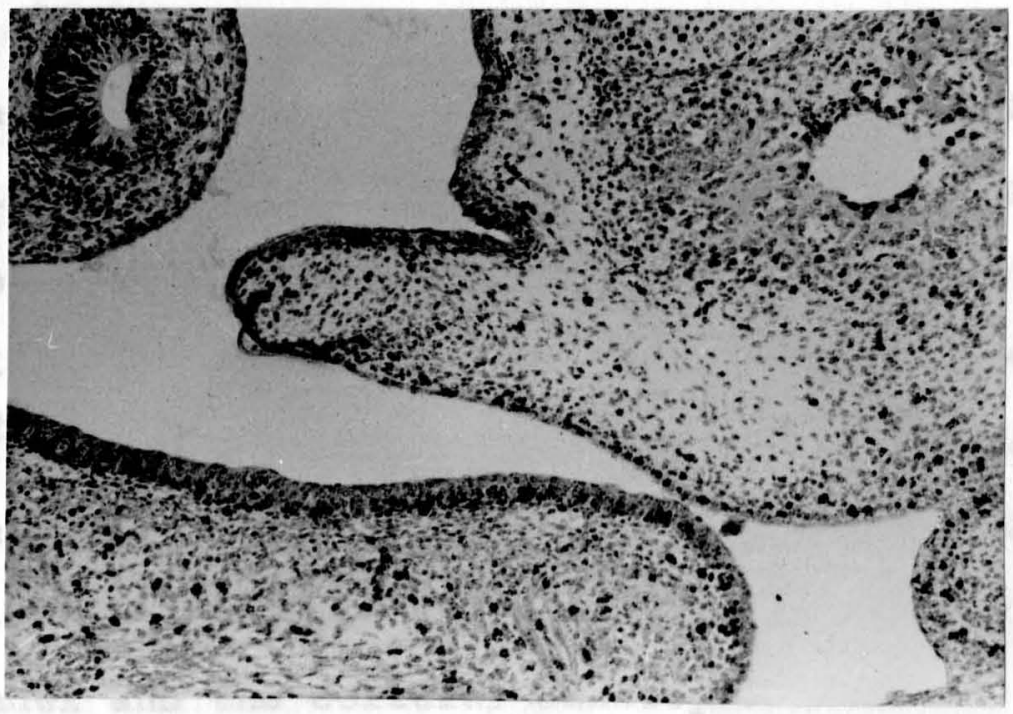

Fig. 4C (100x) 
Four fetuses from each age group were used for the mitotic labeling index and cellular density counts. The number of labeled cells per 1000 cells in the 15k day normal mouse palate was 229, 218, 210, and 223. In the 151/ day cleft palate mouse, the number of labeled cells per 1000 cells was $164,155,146$, and 149. In the cellular density counts, the average number of cells per $.25 \mathrm{~mm}^{2}$ was 10.13 for the $15 \frac{1}{2}$ day normal palate and 12.96 for the 15 day cleft palate mouse.

The students " $t$ " test was used to determine if there was a significant difference in the number of labeled celis and in the number of cells per $.25 \mathrm{~mm}^{2}$. In both cases, the alfference was highly significant $(p=.001)$.

In the $16 \frac{1}{2}$ day normal mouse palate, the number of labeled cells per 1000 cells was $212,218,235$, and 208 . In the 16t day cleft palate mouse, the number of labeled cells per 1000 cel1s was $136,126,148$, and 130 . The average number of cells per $.25 \mathrm{~mm}^{2}$ was 9.25 in the $16 \frac{1}{2}$ day normal mouse palate and 13.15 in the $16 \frac{1}{2}$ day cleft palate mouse. The students " $t$ " test was also highly significant $(p=.001)$ for both the mitotic labeling Index and the cellular denstty counts.

The Increased cell density Indicates that the cells are packed closer together in the cleft palate mice compared to the 
normal mice. The fact that there are more cells per unit area in the cleft palate mice indicates that conversely there is less intercellular substance (acid mucopolysaccharides) within the same unit area.

The palatine shelves consist of a core of loose connective tissue surrounded by epithelium. There was bone present in the base of the palatine shelves, but not in the shelf portion. In the sections stained with PAS, the connective tissues of the palatine shelves were PAS-positive, Indicating the presence of neutral mucopolysacchartdes. The Intercellular substance stained a light magenta and the cytoplasm of the cells stained a darker magenta. The nuclel appeared to be light blue.

In the alcian blue-pas sections, the Intercellular substance stained a light blue indicating the presence of acla mucopolysaccharides. The cells in the base of the connective tIssue were a darker turquoise blue. The cell boundary is deeply stained and the stain intensity decreases toward the center of the cell. The bone belng formed in the base of the shelves was a dark purple.

In the alclan blue-aldehyde fuchsin sections, the intercellular substance stained a light blue color. The cytoplasm of the cells stained a darker blue compared to a very light 
38

blue nucleus. Both the cartilage of the nasal septum and Meckel's cartilage exhibited a blulsh-violet color. 


\section{CHAPTER V}

\section{DISCUSSION}

Th1s investigation shows there are signiflcantly $(p=.001)$ fewer labeled cells per 1000 cells in the palatine shelves of cleft palate mice as compared to normal mice. since the labeled tritiated thymidine is picked up by the cells that are preparing to undergo mitosis, the decreased amount of labeling in the palatine shelves of cleft palate mice indicates that there are less cells being produced in these mice.

Although gross or microscopic measurements were not done In this investigation, it was observed that the palatine shelves of cleft palate mice appeared smaller than those of normal mice. This is substantiated by the fact that there were less cells in the palatine shelves of the cleft palate mice than in the normal mice. It has been shown however, that the palatine shelves of cleft palate mice are maller than those of normal mice (Walker, 1954). It was also shown that the palatine shelves of cleft palate mice (whlch undergo horizontalization at day 15/8) are the came size as the shelves of normal mice which undergo horizontallzation at day $14 / 8$.

Due to the retarded growth of the palatine shelves of 
cleft palate mice, they are unable to keep up with the growh in width of the head. Therefore, once the shelves bacome horizontal, they are unable to fuse ince they cannot come into contact with each other.

The defloteney in the number of cells is also signifloant Elnce the cella produse the acid micomolysaccharides. A decreased number of cells therefore Indlates there should aleo be a corresponding decrease in the mount of interoellular substanoe (acld mucopolyseccharides) produced in the palatine shelves of eleft palate nice. This was subatantiated by the cellular density counts. The decrease in the number of celle per $.25 \mathrm{man}^{2}$ in the normal mouse palate comparad to the eleft palate moves proved to be hlghly elgnifloant (p - .001).

A deflelent anount of Intercellular mubstance lacld mucopolysaccharides) at the time of normal horixontalixation can be consldered major factor in the development of eleft palate. The eynthesis of sulphated anda macopolyaaccharides is constaered responsible for the bulld up of an internal presare Within the shelves. This agrees with Walker (2960) and Larsaon (1962) who have shown there $1 \mathrm{~s}$ a greater $5^{35}$ uptak in the palatine shelves erom day $14 / 8$ to $14 / 18$ than there is from $1.2 / 10$ to 14/8. They have also shown that there 18 a 
considerably greater uptake of $\mathrm{s}^{35}$ in the normal mouse embryonlc palatine shelves than there 13 in the oleft palate mice. Th1s increased $\mathrm{s}^{35}$ uptake indicates a sulphated acid mucopolysaccharide aynthesis prior to horlzontalization of the palatine shelves in normal mice.

It was demonstrated that the upward movement of the palatine shelves is retarded in mouse embryos who have been given cortisone at a prescribed time during gestation. This correlates with the findings of Walker and Fraser (1956) and Larsson (1962). The exact mechanism of cortisone action on the connective tissues of the palatine shelves is unknown however. Due to the decreased amount of labeled cells in the cleft palate mice, it can read1ly be seen that cortisone depresses the mitotic aotivity of the cells. This has also been shown by Bullough (1952) and Roberts (1952).

The decreased amounts of intercellular substance in cleft palate mice indleates that cortisone interferes with the formation of ac1d mucopolysaccharldes by the oells and/or the decreased number of cells is the reason for less intercellular substance.

The procese of sulphation Increases the gelation and viscosity of the acld mucopolysaccharldes. The adhestve 
properties of the acid mucopolysaccharides (Toto and Grandel, 1956) are also responsible for the binding of $\mathrm{H}_{2} \mathrm{O}$ and electrolytes. A decreased synthests of acid mucopolysaccharides and/or a chemical altexation (i.e., interference of sulphation) due to the cortisone action would interfare with the binding properties, elasticlty and swelling capacities of the intercellular substance. This interference causes delay in the build up of the internal shelf pressure and thus a delay in the horizontalization of the palatine shelves.

This agrees with Walker (1960) who stated the only modification necessary to enable the intercellular substance (acid mucopolysaccharides) to bring about movement of the palatine shelves is that it should not be in 1 ts conformation of maximun stability prior to the actual movement. He thought that the instability might be cue to asymetrical deposition and subsequent growth stresses, to qrowth pressures from outside sources, or to chemical alteration of the material itself. It is not known at present whether such mechanisms are possible, or whether any of them exist in the embryo. However, an interference in the synthesis of acid mucopolysaccharides due to cortisone would not allow the intercellular substance in the palatine shelves to be in the "state of maximum stability" at 
the time of normal horlzontalization as declared by walker. Many cleft palate microscopic sections were seen in which one palatine shelf was horizontal and the other was vertical. The tongue did not appear to have dropped since it was still medial to the vertical shelf. Th1s was described by walker (1954) who classified it as stage 111 of palatal clogure. He also sald there was no sign of the tongue having dropped, thus allowing the shelves to become horizontal as suggested by peter (1926) and Lazarro (1942). Because this stage of palatal closure appears so frequently, Walker felt that the tongue played a passive role in the closure of the secondary palate. It is doubtful that the tongue is entirely passive in the process of palatal closure since it must at least change shape to accomodate the changes in shelf position curing palatal elosure.

It was not possible to determine any difference in the staining intensities of the palatine shelves in cleft palate and normal mice. A syatem of assigning plus signs according to the degree of intensity was initlated, but was discarded. However, the special stains were excellent in showling the various staining capacities of the acid mucopolysaccharides. 


\section{CHAPTER VI \\ SUMMARY AND CONCLUSIONS}

Pregnant female mice were injected with cortisone to Induce cleft palates in their offepring. $2.5 \mathrm{mg}$. of cortisone acetate was infected in the flank of the pregnant female mice on the 11th, 12th, 13th, and 14 th day of the gestation period. The cortisone treated mice and the controls were sacrificed at $15 \frac{1}{2}$ and $16 \frac{1}{2}$ days in utero (one hour after intraperitoneal injection of .5cc tritiated thymiaine).

The number of labeled cells per 1000 cells and the number of cells per $.25 \mathrm{~mm}^{2}$ in the base of the palatine shelves were counted.

There were significantly more labeled cells per 1000 cells in the shelves of normal mice than in cleft palate mice. The decreased number of labeled cells Indlcates there are less cells preparing to undergo mitosis, and consequently, a decreased cellularity in the shelves of cleft palate mice.

There $1 \mathrm{~s}$ a greater cell density in the palatine shelves of cleft palate mice than in normal mice. This results in a deficient amount of Intercellular substance (acid mucopolysaccharides). This deficiency in intercellular substance 
45

causes a delay in the horlzontalization of the palatine shelves. The antimitotic effect of cortisone and/or a chemical alteration of the cells results in a deficiency in the number of cells and therefore less intercellular substance.

It was not possible to determine any differences in the staining intensities in the palatine shelves of cleft palate and normal mice. 


\section{BIBLIOGRAPHY}

Asboe-Hansen, G. 1952. The mast cell. Cortisone action on connective tissue. Proc. Soc. Expt'1. Biol. and Med." $80: 677-679$.

1954. Connective Tissue in Health and Disease. Copenhagen, Efnar Munksgaard, Publisher.

1958. Hormonal effects on connective tissue. Physiol Rev., $38: 446-462$.

Ashton, N. and Cook, C. 1952. In vivo observations of the effects of cortisone upon the blood vessels in rabbit ear chambers. Brit. J. Bxpt'1. Biol. and Med., 33:445-450.

Baxter, H. and Fraser, F. 1950. The production of congenital defect in the offepring of female mice treated with cortisone. MoG111 Med. Journ.,19:245-249.

B1rke, G. 1953. The dermal spreading of hyaluronidase and streptococal under the influence of atress (cold), ACTH, cortisone, desoxycorticosterone acetate. Acta. Med. Scand., 144:455-466.

Boyd, G. and Williams, A. 1948. Stripping film techniques for histological autoradiographs. Proc. Soc. Expt'i. Blol. and Med., 69:222-232.

Bullough, W. 1952. Stress and epidermal mitotic activity. 1. The effects of the adrenal hormones. Jour.Endocrinology. $8: 265-274$.

Bunting, H. 1950. The distribution of acid mucopolysaccharides in maramalian tissues as revealed by histochemical methods. Ann. New York Aced. Sc1.,52:977-982.

Bone Structures and Metabolim: CIBA Foundation and Symposium. Ittele, Brown and Co. Boston, 65-75. 1956.

Callas, G. and Walker, B. 1963. Palate Morphogenesis in mouse embryos after $x$-1rradiation. Anat. Rec. 145:61-72. 
Cavallero, C. and Braccini, C. 1951. Effect of cortisone on the mast cells of the rat. Proc. Soc. Bxpt'1. B101. and Med., $69: 222-232$.

Coleman, R. 1965. Development of the rat palate. Anat. Rec., $151: 107-112$.

Cronkite, E., Bond, V., Fliedman, T., and Rubine, J. 1959. The use of tritiated thymidine in DNA synthesis and cell turnover in hemopoletic tissue. Lab. Invest., Vol. 8, No. 1.

Dorfman, A. 1961. Biochemistry of Connective Tisgue: Conference on the Biology of Connective Tismue CeIIs.

1956. The metabolism of mucopolysaccharides. Proc. Intern. Conf. on the Peaceful use of Atomic Energy. 12:286.

Firket, H, and Varly, W. 1957. Autographlc viguallzation of DNA in tissue culture with tritiated thymidine. Nature, 1812274 .

Fitzgerald, R., Eidenoff, M., Knoll, J., and Simnel, E. 1951. Tritiun in Autoradlographs. Science, 114:494-498.

Fitzgerald, P., Simmel, E., Welnstein, J., and Martin, C. 1953. Radioautography: Theory, Technique and Applications. Lab. Invest., 2:181-182.

Fraser, F. and Fainstat, T. 1951. Production of congenital defects in offepring of pregnant mice with cortisone and other hormones. Pediatrics, 8:527-533.

Fraser, F., Kalter, H., Walker, B., and Fainstat, T. 1954. The experimental production of cleft palate with cortisone and other hormones. J. Cell. and Comp. Physio. 43:237-259.

Gersh, I., and Catchpole, H. 1949. The organlzation of ground substance and basement membrane and 1 ts 1 igniflcance for tissue Injury, ilsease and growth. Am. J. Anat. 85:457521.

Heiberg, K., Kalter, H., and Fraser, F. 1959. Production of cleft palate in the offspring of mice treated with ACTH during pregnancy. Biol. Neonatal, 1:33-37. 
Huges, W., Bond, v., Brecker, G., Cronkite, E., Painter, R.. Quaster, H., Sherman, F. 1958. Cellular prollferation in mouse as revealed by autoradlographs with tritlated thymidine. Proc. Nat. Acad. Sci. 44:476-483.

Ingal1s, R. 1957. Relation of hydrocortisone injections to cleft palate in mice. New England Journal Med. 256: 1035-1039.

Ingalls, R., and Curley. 1957. Factors influencling the frequency of cortisone induced cleft palate in mice. J. Exp. zool. $134: 449-467$.

Isaccson, R, and Chaudry, A. 1962. Cleft palate Induction in strain A mice with cortisone. Anat. Rec. 142:479-484.

Jacobs. R. 1964. Preliminary survey of the effects of cortisone upon palate formation, litter size and fetal weight in CD-1 strain of mice. Jour. Dent. Research. 43,\$5:715.

Ibld. 1964. Histochemical study of morphogenesis and teratogenesis of the palate in mouse embryos. Anat. Rec. 149: 691-698.

Kalter, H. and Fraser, F. 1953. The modiflcation of the teratogenic action of cortisone by parity. Sclence. 118:625-626.

Kalter, H. 1954. Inheritance of susceptibility to teratogenic action of cortisone in mice. Genetics. 39:185-196.

1957. Factors influencing the frequency of cortisone Induced cleft palate in mice. J. Exp. Zool. 134:449-468.

Kalter, H. and Markany. 1959. Experimental production of congenltal malformations in mammals by metabolic procedure. Physio. Rev. 39:69-115.

Lajtha, I., Ph11, D., and Oliver. R. 1959. The application of autoradlography in the study of nucleic acid metabolism. Lab. Invest., Vol. 8, No. 1 .

Iarsson, K., Bostrom, H., and Cars100, R. 1959. Studies on the closure of the secondary palate, I. Experimental Cell Research, $16: 379-383$. 
Larsson, K. 1961-62. Studies of the closure of the secondary palate, III. Autoradiographic and histochemical studies in the normal mouse embryos. Acta Morph. Neerl. Scand. $4: 349-367$.

1961-62. Studies on the closure of the secondary palate, IV. Autoradiographic and histochemical studies of mouse embryos from cortisone-treated mothers. Acta Morph. Neerl. Scand. 4:369-386.

1962. Studies on the closure of the secondary palate. Acta Odont. Scand. 20:1-13.

Lattes, R., Blunt, J., Rose, H., Jessar, R., Vaillancourt, G., Ragan, $C$. Lack of cortisone effect in the early stages of Inflarmation and repair. Am. J. Path. 29:1-19.

Layton, I. 1951. Cort1sone Inhibition of mucopolysaccharide synthesis in the intact rat. Arch. Biochem. 32:224.

1951. Effect of Cortisone upon chondroitin sulfate synthesis by animal tissues. Proc. Soc. Exp. B101. 76: 596-598.

Lazzaro, C. 1940. Sul meccanisimo di chlasura del palato secondario. Monit. Zool. Ital, 51:249-265.

Leblond, C., Messier, B., and Kapriwa, B. 1959. Thymidine $\mathrm{A}^{3}$ as a tool for the investigation of renewal of cell population. Lab. Invest., Vol. 8, No. 1.

Loevy, H. 1962. Developmental changes in the palate of normal and cortisone treated Strong $A$ mice. Anat Rec., 142: 375-390.

McManus, J., and Mowry, R. Staining Methods: Bistologlc and Biatochemical. Heober Inc. New Tork, 1960.

Meyer, K. 1947. The blological signiflcance of hyaluronic acid and hyaluronidase.. Physio. Rev., 27:335-339.

1955-56. The chemistry of the mesodermal ground substances. The Harvey Lectures, 51:Copy 2, 88-111. 
1961. Biochemistry of connective tissue: conference on the biology of connective tissue cells.

Mowry, R. 1956. Alcian Blue. Techniques for the histochemical study of acldic carbohydrates. J. Hlstochem. and Cytochem., 4:407.

Paff, G. and Stewart, R. 1953. Free wandering cells and cort1sone. Proc. Soc. Exp. Biol. and Med.. 83:591-592.

Pearse, A. Histochemistry, Theorhetical and Applied. Little, Brown and Co. Boston. 1953 .

Pelc, S. 1947. Autoradiograph1c technique. Nature, 160:749-750.

Peter, K. 1924. Die entwicklung des saugetlergaumens. Exgebn. Anat. Entwicklungggesch, 25:448-564.

Plotz, C., Howes, E., Blunt, J., Meyer, K., and Ragan, C. 1950. Action of cortisone on mesenchymal tissues. Arch. Derm. Syph., 61:919-921.

Polz1, A. 1904. Sur Entwickelungsgeschiete des manschlichen. Gaumens. Anat. Hefte, 27:244-301.

Pons-Tortella, E. 1937. Uber die bildungswelse des sekundaren. Gaumens. Anat. Ans. , 84:1347.

Ragan, C., Howes, E., Plotz, C., Meyer, K., and Blunt, J. 1949. Effect of cortisone on production of granulation tissue in rabbit. Proc. Soc. Exp. B1ol. and Med., 72:718-721.

Ragan, C., Howes, E., Plotz, C., Meyer, K., Blunt, J., and Lattes, R. 1950. The effect of ACTH and cortisone on connective t1ssue. Bul1. N.Y. Acad. Med., 26:251-254.

Reed, S. C. 1933. An embryological study of harelip in mice. Anat. Rec., 56:101-110.

Roberts, K., Florey, H., and Joklik, W. 1952. The influence of cortisone on cell division. Quart. J. Exp. Physiol.,

Snel1, C. Biology of the Laboratory Mouse (Jaokson Laboratory). Blakiston Co. New York. 1941. 
Snell, C., Fekete, E., Humel, K., Law, I. 1940. The relation of mating, ovulation and the estrus smear in the house mouse to the time of day. Anat. Rec., 76:39-54.

Stark, R. 1954. The pathogenes1s of harelip and cleft palate. Plastic and Reconstruct1ve Surgery, 13:20-39.

Toto, P. Personal Communication.

Toto, P., and Grandel, E. 1966. Acld mucopolysaccharides in the oral eplthellum. Peridont1cs, Vol. 4, No. 3:127-130.

Walker, B. 1954. Genetico-embryological studies on normal and cleft palates in mice. Ph.D. Dissertation. McGill Univ.

Walker, B., and Fraser, F. 1956. Closure of the secondary palate in three strains of mice. J. Embryol. and Exp. Morph.. $4: 176-189$.

Walker, B. 1960. A special component of embryonic mesenchyme. Anat. Rec., 136:298.

1961. The association of mucopolysaccharides with morphogenesis of the palate and other structures in mouse embryos. J. Embryol. Exp. Morph., 9:22-31.

Whitehouse, P. 1960. Effect of cortisone, hydrocortisone and some of their synthetic analogues upon the blogenesis of cartilage in vitro. Acta. Endocrinol Suppl., $51: 957$. 


\section{APPENDIX \\ TABLE 1

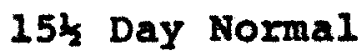

Fetus No.

1-1

No. labeled cells/1000 cells

229

No. $\operatorname{cel} 18 / .25 \mathrm{~mm}^{2}$

$\begin{array}{lllll}12 & 11 & 10 & 9 & 10\end{array}$

$\begin{array}{lllll}8 & 10 & 9 & 13 & 11\end{array}$

$\begin{array}{lllll}11 & 9 & 12 & 11 & 10\end{array}$

$\begin{array}{lllll}10 & 11 & 10 & 10 & 8\end{array}$

$\begin{array}{lllll}12 & 10 & 9 & 9 & 10\end{array}$

1-3

218

$\begin{array}{rrrrr}9 & 11 & 10 & 10 & 12 \\ 9 & 10 & 8 & 10 & 9 \\ 10 & 11 & 9 & 10 & 10 \\ 10 & 10 & 12 & 9 & 11 \\ 12 & 10 & 11 & 9 & 11\end{array}$

$1-\AA$

210

$\begin{array}{lllll}11 & 10 & 10 & 13 & 10\end{array}$

$\begin{array}{lllll}10 & 9 & 12 & 8 & 9\end{array}$

$\begin{array}{lllll}9 & 10 & 9 & 10 & 10\end{array}$

$\begin{array}{lllll}8 & 11 & 12 & 11 & 12\end{array}$

$\begin{array}{lllll}10 & 9 & 10 & 11 & 9\end{array}$

$1-4$

223

$\begin{array}{lllll}10 & 12 & 10 & 11 & 11\end{array}$

$\begin{array}{lllll}8 & 9 & 9 & 11 & 11\end{array}$

$\begin{array}{lllll}9 & 10 & 12 & 10 & 10\end{array}$

$\begin{array}{lllll}9 & 10 & 12 & 9\end{array}$

$\begin{array}{lllll}11 & 10 & 9 & 10 & 10\end{array}$ 


\section{TABLE 2}

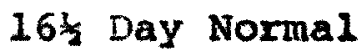

Fetus No.

No. labeled cells/1000 cells

212

$1 v-1$

IV-2

218

$\begin{array}{rrrrr}11 & 8 & 10 & 9 & 11 \\ 10 & 10 & 11 & 9 & 10\end{array}$

$\begin{array}{lrrrr}8 & 9 & 9 & 10 & 9\end{array}$

$\begin{array}{lllll}10 & 10 & 10 & 10 & 9\end{array}$

$\begin{array}{lllll}10 & 9 & 10 & 9 & 10\end{array}$

IV-6

235

$\begin{array}{lllll}10 & 7 & 9 & 10 & 7\end{array}$

$\begin{array}{lllll}7 & 10 & 9 & 10 & 9\end{array}$

$\begin{array}{lllll}10 & 8 & 10 & 9 & 9\end{array}$

$\begin{array}{lllll}9 & 10 & 10 & 8 & 10\end{array}$

$\begin{array}{lllll}8 & 10 & 11 & 12 & 8\end{array}$

$2 v-3$

208

$\begin{array}{lllll}11 & 13 & 12 & 10 & 8\end{array}$

$\begin{array}{rrrrr}9 & 8 & 13 & 8 & 7 \\ 10 & 7 & 7 & 10 & 10\end{array}$

$\begin{array}{rrrrr}9 & 10 & 9 & 11 & 8 \\ 10 & 7 & 7 & 8 & 8\end{array}$ 


\section{TABLE 3}

15/ Day Cleft Palate

Fetus No

111-1

No. Iabeled ce11s/1000 cells

164

No. $\operatorname{cel} 1 \mathrm{~s} / .25 \mathrm{~mm}^{2}$

$\begin{array}{rrrrr}9 & 14 & 14 & 15 & 12 \\ 15 & 12 & 14 & 12 & 9 \\ 17 & 12 & 13 & 17 & 11 \\ 10 & 11 & 15 & 13 & 12 \\ 9 & 12 & 10 & 11 & 12\end{array}$

111-2

155

$\begin{array}{lllll}16 & 14 & 14 & 16 & 12\end{array}$

$\begin{array}{lllll}16 & 14 & 12 & 14 & 14\end{array}$

$\begin{array}{lllll}16 & 14 & 14 & 13 & 11\end{array}$

$\begin{array}{lllll}16 & 16 & 16 & 16 & 15\end{array}$

$\begin{array}{lllll}15 & 16 & 15 & 13 & 13\end{array}$

111-3

146

$\begin{array}{lllll}13 & 12 & 12 & 13 & 12\end{array}$

$\begin{array}{lllll}12 & 12 & 15 & 13 & 13\end{array}$

$\begin{array}{lllll}15 & 12 & 15 & 14 & 14\end{array}$

$\begin{array}{lllll}14 & 11 & 13 & 12 & 11\end{array}$

$\begin{array}{lllll}13 & 14 & 14 & 15 & 12\end{array}$

$111-4$

149

$\begin{array}{lllll}13 & 12 & 13 & 9 & 11\end{array}$

$\begin{array}{lllll}13 & 12 & 13 & 10 & 11\end{array}$

$\begin{array}{lllll}10 & 11 & 10 & 11 & 14\end{array}$

$\begin{array}{lllll}14 & 13 & 15 & 14 & 11\end{array}$

$\begin{array}{lllll}14 & 14 & 13 & 14 & 13\end{array}$ 


\section{TABLE 4 \\ 164 Day cleft Palate}

Fetue No.

No. labelad Cel1s/1000 cella

$11-1$

136

No. $\operatorname{ce} 118 / .25 \operatorname{man}^{2}$

$\begin{array}{lllll}14 & 12 & 11 & 10 & 15\end{array}$

$\begin{array}{lllll}15 & 13 & 10 & 15 & 10\end{array}$

$\begin{array}{lllll}15 & 13 & 14 & 10 & 6\end{array}$

$\begin{array}{lllll}11 & 13 & 14 & 14 & 9\end{array}$

$\begin{array}{lllll}13 & 10 & 10 & 14 & 11\end{array}$

$11-2$

126

$\begin{array}{lllll}14 & 11 & 15 & 12 & 13\end{array}$

$\begin{array}{lllll}13 & 12 & 15 & 10 & 15\end{array}$

$\begin{array}{lllll}12 & 15 & 16 & 13 & 12\end{array}$

$\begin{array}{lllll}15 & 13 & 10 & 14 & 14\end{array}$

$\begin{array}{lllll}23 & 14 & 12 & 15 & 16\end{array}$

11-3

148

$\begin{array}{lllll}13 & 13 & 14 & 14 & 15\end{array}$

$\begin{array}{lllll}12 & 12 & 10 & 14 & 12\end{array}$

$\begin{array}{lllll}12 & 11 & 10 & 16 & 11\end{array}$

$\begin{array}{lllll}14 & 12 & 12 & 14 & 12\end{array}$

$\begin{array}{lllll}14 & 14 & 15 & 14\end{array}$

$21-4$

130

$\begin{array}{lllll}15 & 16 & 13 & 16 & 14\end{array}$

$\begin{array}{lllll}13 & 16 & 15 & 16 & 14\end{array}$

$\begin{array}{lllll}13 & 15 & 13 & 15 & 15\end{array}$

$\begin{array}{lllll}15 & 10 & 16 & 16 & 15\end{array}$

$\begin{array}{lllll}14 & 10 & 14 & 17 & 14\end{array}$ 


\section{APPROVAL SHEET}

The thesis submitted by William $J$. Mott has been read and approved by members of the department of oral Biology. The final copies have been examined by the director of the thesis and his signature which appears below verifies the fact that any necessary changes have been incorporated and that the thesis is now given final approval with reference to content, form and mechanical accuracy.

The thesis is therefore accepted in partial fulfillment of the requirement for the degree of Master of science.

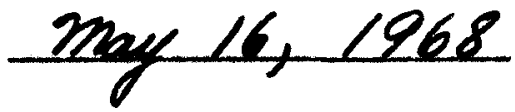

Date

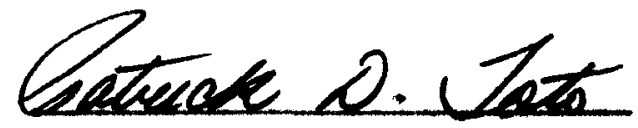

signature of Advisor 